\title{
Ben Barres (1954-2017)
}

Neurobiologist who advocated for gender equality in science.

$\mathrm{B}$ en Barres (born Barbara Barres) was a passionate researcher of the role of glia, the most numerous type of brain cell, in development and disease. He was also an ardent campaigner for equal opportunity in science. He died of cancer aged 63, on 27 December 2017.

As Barbara and as Ben (he transitioned genders in 1997), Barres made numerous landmark discoveries. These include the identification of glial-derived factors that promote the formation and elimination of synapses, and the characterization of signals that induce the formation of myelin, the lipid sheathing on neurons.

Barres devoted much of his last decade to publicly describing the challenges he had faced as a woman in science, and offering ways to correct a system that he viewed as fundamentally biased against the advancement of women and minorities. He also called for mentors to be held more accountable for the training and success of their graduate students and postdocs.

Barres took tremendous pleasure from working on important but neglected problems. "Ninety-nine per cent of neuroscientists work on $1 \%$ of the interesting questions," he said, "It is so much more exciting to work on the untouched mysteries!" His findings and vocal presence at meetings were largely responsible for the acceptance that glial cells contribute to brain development, function and disease.

Barres was raised in West Orange, New Jersey and loved mathematics and science from an early age. He never felt comfortable being treated as a girl. At school, Barres repeatedly requested, but was denied, access to courses in science and engineering. A summer science programme with no gender restrictions at Columbia University in New York City finally provided access to these subjects, and led him to pursue a bachelor of science degree in biology at the Massachusetts Institute of Technology in Cambridge.

In 1979, Barres completed a medical degree at Dartmouth College in Hanover, New Hampshire, and then a neurology residency at Weill Cornell Medicine in New York City. He was intrigued that so many of the diseases that impair brain and nervous-system function involve glial cells, yet so little was known at the time about their biology.

Barres left medicine to do a doctorate in neurobiology at Harvard Medical School

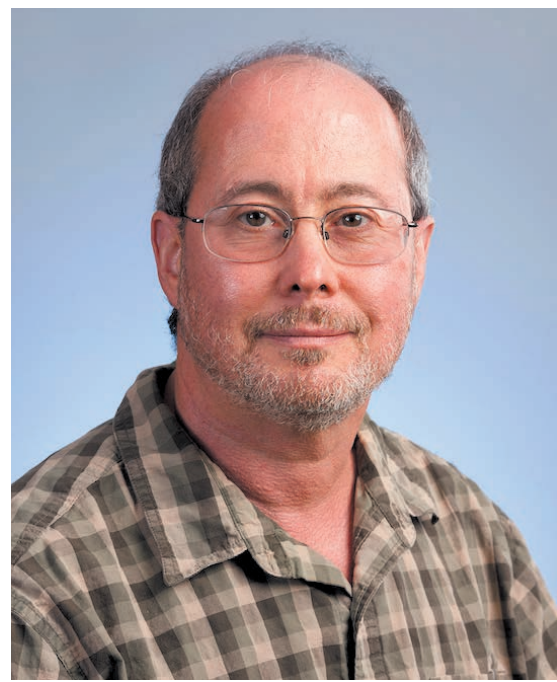

in Boston, Massachusetts, on the function and distribution of cation channels in glial cells. During a postdoc at University College London, Barres discovered that developing neurons provide signals to the myelinating glial cells - the oligodendrocytes - to insulate neuronal axons.

Barres started his own lab in 1993, in the neurobiology department at Stanford University School of Medicine in California. He mentored dozens of students and postdocs. Barres' lab meetings were legendarily intense. They often lasted three hours or more owing to the large number of people in attendance, the vast range of topics covered and the open, somewhat unstructured discourse that Barres encouraged.

Barres insisted that people in his lab tackle important scientific problems, voice their views and ask questions at conferences. $\mathrm{He}$ allowed his trainees immense freedom to collaborate with others, to work whatever hours they wanted and to attend any meeting they cared to - as long as they asked questions. Many went on to faculty positions in the United States, Europe or Asia.

The Barres lab made many discoveries about how synapses form in the developing brain. It probed the roles of different types of glial cell - astrocytes and microglia in synapse elimination, for example. Barres also made significant contributions to the study of signals that influence the survival of damaged neurons, optic-nerve and spinalcord regeneration, and the assembly and maintenance of the barrier that prevents specific molecules in the blood entering the brain. In 2013, Barres was elected to the US National Academy of Sciences - the first openly transgendered member.

Ben had an almost superhuman work ethic. Working 18-20 hours per day didn't feel difficult, he told me, because, "science is fun ... almost like a playful addiction". In his later years, Ben started cycling in the hills around Stanford. He also began roasting his own coffee beans - giving bags to lab members in exchange for constructive feedback. He delighted in all things Harry Potter. Trips to the latest film were among the few mandatory requirements of Barres-lab membership.

In April 2016, Ben was diagnosed with advanced pancreatic cancer. Amid repeated treatments, he continued to work every day, write grant applications and manuscripts, and keep up his advocacy. He never stopped mentoring his students and postdocs, and toiled feverishly to update and archive their letters of support in anticipation of their future career developments after his death.

Ben confided that he'd never had much interest in romantic relationships or having children. He told me: "I've always considered my colleagues as my family, and my students and my postdocs as my children." Seeing them flourish and succeed was one of his greatest sources of joy.

Ben's colleagues and protégés adored him and considered the Barres lab a family of sorts, too. As far back as I can recall, the hallway doors of Ben's lab were adorned with drawings and photos of the various lab members - past and present, their children and their pets and, of course, glial cells. We were and remain bonded by our affection and appreciation for Ben, his dedication to mentoring us, his quirks, and his unrelenting spirit.

Barres was remarkably brave and reflective about his illness and the life he'd led. As he put it: "I lived life on my terms: I wanted to switch genders, and I did. I wanted to be a scientist, and I was. I wanted to study glia, and I did that too. I stood up for what I believed in and I like to think I made an impact, or at least opened the door for the impact to occur. I have zero regrets and I'm ready to die. I've truly had a great life."

Andrew D. Huberman is a professor of neurobiology at Stanford University School of Medicine, California, and a former postdoc in the Barres lab. He was a close friend of Ben's. e-mail:adh1@stanford.edu 